\title{
DNA Replication ATP-Dependent Helicase/Nuclease DNA2
}

National Cancer Institute

\section{Source}

National Cancer Institute. DNA Replication ATP-Dependent Helicase/Nuclease DNA2. NCI Thesaurus. Code C117093.

DNA replication ATP-dependent helicase/nuclease DNA2 (1060 aa, 120 kDa) is encoded by the human DNA2 gene. This protein is involved in Okazaki fragment processing and DNA double-strand break repair. 